\title{
Employee Turnover in banking sector: Empirical evidence
}

\author{
${ }^{1}$ Santript Shukla, ${ }^{2}$ Dr. Ambalika Sinha \\ ${ }^{I}$ Santript Shukla_Scholar DHSS, MNNIT, India \\ ${ }^{2}$ Dr. Ambalika Sinha_Asst. Professor DHSS, MNNIT, India
}

\begin{abstract}
Employee turnover" as a term is widely used in business circles. Although several studies have been conducted on this topic, most of the researchers focus on the causes of employee turnover. This research looked at extent of influence of various factors on employee turnover in urban and semi urban banks. The research was aimed at achieving the following objectives: identify the key factors of employee turnover; determine the extent to which the identified factors are influencing employees' turnover. The study is based on the responses of the employees of leading banks. A self-developed questionnaire, measured on a Likert Scale was used to collect data from respondents. Quantitative research design was used and this design was chosen because its findings are generaliseable and data objective. The reliability of the data collected is done by split half method.. The collected data were being analyzed using a program called Statistical Package for Social Science (SPSS ver.16.0 For Windows). The data analysis is carried out by calculating mean, standard deviation and linear correlation. The difference between means of variable was estimated by using $t$-test. The following factors have significantly influenced employee turnover in banking sector: Work Environment, Job Stress, Compensation (Salary), Employee relationship with management, Career Growth.

Key words: Employee Turnover, Job Stress, Work Environment, Career Growth SPSS, T-Test,
\end{abstract}

\section{Introduction:-}

Human resource is considered to be the center of all development processes of economy. But today's competitive business scenario is deteriorating social conditions of human resources, hence causing employee turnover. According to Price (1977) employee turnover is the ratio of the number of organizational members who have left during the period being considered divided by the average number of people in that organization during the period. The "seeds" or initial causes of turnover, arising out of the frustration related to budget cutting, hiring freezes, layoffs, and lack of development funds and opportunities, are more likely to be sown at such times.(Sharmistha, 2010) High turnover rate is problematic and have a negative impact on an organization's performance.

After independence, year 1991 was the marked as the significant year for Indian banking sector. In year 1969 after nationalization of 14 major banks a great reform arise in banking sector in India. Followed by globalization, liberalization and other international events lead banking sector in India to reform and adjust to attain competitive edge in multinationals environment. In order to cope with the changing trend as well to provide effective and efficient service to the customer implementation of advance technology has changed the face of banking. Installation of ATM machine, e-Banking, computer implementation and lot many inputs have changed the work patterns of the bank employees. Directly or indirectly these reforms in policy and technology in banking sector has deteriorated the social, economic and psychological sphere of the bank employees in India.

According to Kevin et al (2004), although there is no standard framework for understanding employee's turnover process as whole, a wide range of factors have been found useful in interpreting employee turnover. The pattern in Indian banking sector is also influenced with the same factors such as lack of training, poor working condition, workplace conflict, ineffective leadership etc.

Hence in this study with the implementation of Statistical Package for Social Science (SPSS ver.16.0 For Windows) major factor of turnover is being analyzed and hierarchy was defined.

\section{Literature Review:-}

"Employee turnover is a ratio comparison of the number of employees a company must replace in a given time period to the average number of total employees (Agnes, 1999). A huge concern to most companies, employee turnover is a costly expense especially in lower paying job roles, for which the employee turnover rate is highest (Samuel, 2012). Turnover refers to the amount of movement of employees in and out of an organization, normally present in terms of the turnover rate (Chruden \& Sherman, 1972). Mobley (1982) gave the meaning of employee turnover as the discontinuance of membership in an organization by the person who received monetary compensation from the organization. Tanke (2001) has defined turnover as the movement of 
employees out of the organization. Carley (1992 quoted in Tham, Pee, Kankanhalli \& Tan, 2008) states that employees turnover means the rotation of workers around the labour market, between organizations, jobs and careers. Many factors play a role in the employee turnover rate of any company, and these can stem from both the employer and the employees. Wages, company benefits, employee attendance, and job performance are all factors that play a significantrole in employee turnover.(Bean, 2009). Mobley et al. (1979) [1] suggested two factors that are related to the employee's progression through successive stages of withdrawal. One factor reflects the employee's evaluation of the organization's future expected value and the tension associated with the employee's present work conditions. In turnover process everyone usually points out one factor for their turnover choice, but there are always more factors on the back hand that works as push-cart or driving force for that factor(Jaffari, 2011). Although, there is no standard framework for understanding the employees turnover process as whole, a wide range of factors have been found useful in interpreting employee turnover Kevin et al. (2004). It was found that employee goal setting (Medlin and Green 2009); career growth (Hamel and Breen, 2007), work environment (Cardoso and Monfardini, 2008; Hansen, 2008 and Burke and Hsieh, 2006), job satisfaction (Palazzo and Kleiner 2002; Garcia and Kleiner 2001; Hannay and Northam 2000 and Stein, K. 1996), training and development (Walsh and Taylor 2007; Shaw et al., 1998; Huselid, 1995) are the foremost decisive factors and very strong predictors of employee turnover intention. Hence keeping in mind the Indian economic context following few factors was studied in order to access employee turnover in banks.

\section{Work Environment:}

If working conditions are substandard or the workplace lacks important facilities such as proper lighting, furniture, restrooms and other health and safety provisions, employees will not be willing to put up with the inconvenience for long time. ( SHAMSUZZOH \& SUMON) Organizational instability has been shown to have a high degree of high turnover. Indications are that employees are more likely to stay when there is a predictable work environment and vice versa (Zuber, 2001). In organizations where there was a high level of inefficiency there was also a high level of staff turnover (Alexander et al.,1994). For employer loosing a single key worker may decreases the like hood of project success and investor confidence can be reduce in the company. Main causes of Turnover are Salaries Working environment and security of job. Turnover particularly arises from unhappiness from job place. In contrary employee also pushed to leave job due to the dissatisfaction in their present workplace. (Shamsuzzoh \& Sumon)

\section{Job Stress :}

Giga and Hoel in 2003 concluded that high rates of mergers, acquisitions, increasing economic interdependence among countries due to globalization, technological development, and restructuring have changed the organizational work over the last few decades have resulted in time pressure, excessive work demand, role conflicts, ergonomic insufficiencies and problematic customer relationship are causes of stress. Kahn et al. (1964) also consider stress as an environmental stimulus to a person, or an oddity between individual and environment. The experience of job related stress (job stress), the range factors that lead to job related stress (stressors), lack of commitment in the organization; and job dissatisfaction make employees to quit Firth et al.(2004).

\section{Compensation (Salary):}

One common cause of high employee turnover rates is low pay and benefits packages. When a worker is employed in a low-wage position with limited benefits, there is little incentive to stay if a similar employer offers even a slightly higher rate of pay. "While lower paying job roles experience an over all higher average of employee turnover, they tend to cost companies less per replacement employee than do higher paying job roles. However, they incur the cost more often. For these reasons, most companies focus on employee retention strategies regardless of pay levels." (Beam, 2009) Workers who make more, but whose salaries fall short of the going market rate, may feel undervalued at their current companies and look for a company that will pay them what they're worth (Firth et al., 2004). Manu et al. (2004) argue that employees quit from organization due economic reasons. The most common reason for employee turnover rate being so high is the salary scale because employees are usually in search of jobs that pay well. (Hissom, 2009). Low pay is good reason as to why an employee may be lacking in performance. (Rampur,2009). Unequal or substandard wage structures fall under this category as well. "When two or more employees perform similar work and have similar responsibilities, differences in pay rate can drive lower paid employees to quit. Ina like vein, if you pay less than other employers for similar work, employees are likely to jump ship for higher pay, if other factors are relatively equal." (Handelsman, 2009) 


\section{Employee relationship with management:}

Nature of management influence the individuals in terms of values of organization, image and existence or firm (Gregory and Henry, 2005). A poor relationship with the management can be an important reason for the employees to leave their jobs. It is relatively rare for people to leave jobs in which they are happy even offered by higher salary elsewhere (Shamsuzzoh \& Sumon). Employer-employee relationship plays a vital role on turnover.(Nawaj, 2007). Lack of role clarity by management can lead to labour turnover According to Herzberg (1966) supervision is an extrinsic factor and a "dissatisfier" as well as a "demotivator" just like pay. This is because employees tend to perform better when they have under less supervision and freedom to exercise initiatives, judgment and self approach to work. (Mbah S. E.,2012)

\section{Career Growth:}

Larson (2004) says career progress creates stress on employee's understandings of the worth of his or her career prospects. Obstacles in career development can appear at any time during an employee's employment period which serves as stressor for them. These stressors can include an array of problems like being stuck at a position, without any hopes of progress or threats of downsizing (Smith and Cooper, 1994). Career growth is much more important than salary in Europe or America but it is counted equivalent to salary in Asian context (Europhia, 2008). "Moving Up or Moving Out" counts career growth as basic for turnover (Europhia, 2008). High employee turnover could also be due to no potential opportunity for advancements or promotions. Employees prefer other companies which may provide them with higher posts and increased compensation packages. (Rampur, 2009)

\section{Statement of the problem:}

\section{Research Methodology:-}

In a competitive business scenario, organization growth is constraints in employ and retaining the esteemed workforce. High turnover rate is problematic and have a negative impact on an organization's performance. This project has made an attempt to study the key factors responsible for employee turnover in the bank.

\section{Objectives:}

1. To explore the major factor of employee turnover in leading Bank.

2. To find out the correlation of employee turnover and the three parameters used viz: career growth, job satisfaction and work environment.

Study area: The study is based on the responses of the employees of leading banks.

Research design: The study is quantitative in nature; on the basis of three parameter viz: work environment, career development and job satisfaction analysis is carried out.

Data collection: Data collection was based on the primary data. Total sample size was 44, out of which 22 samples have been collected from employees working in bank from more than two years and 22 from those who were working here from less than two years. The questionnaire consists of 23 questions. Initial 8 questions are related with employee's basic information where as in next 15 questions, 5 questions from each parameter namely work environment and career development and job satisfaction were asked.

Data analysis: The collected data were being analyzed using a program called Statistical Package for Social Science (SPSS ver.16.0 For Windows). The data analysis is carried out by calculating mean, standard deviation and linear correlation. The difference between means of variable was estimated by using t-test.

\section{Results:}

- Inter correlation between turnover and parameters used viz, work environment, job satisfaction and career development. The linear correlation is as follows

\begin{tabular}{|l|l|l|}
\hline S. No. & Description & 1 \\
\hline 1 & $\begin{array}{l}\text { Employee } \\
\text { turnover }\end{array}$ & 1.00 \\
\hline 2 & $\begin{array}{l}\text { Work } \\
\text { environment }\end{array}$ & $0.885^{* *}$ \\
\hline 3 & $\begin{array}{l}\text { Career } \\
\text { development }\end{array}$ & $0.371^{*}$ \\
\hline 4 & Job satisfaction & $0.467^{* *}$ \\
\hline
\end{tabular}

**Correlation is significant at the 0.01 level.

*Correlation is significant at the 0.05 level 
The correlation coefficient predicts the strength of linear relation among variables. Hence positive values of the correlation shows that the parameters used strongly influence the turnover rate. As indicated in the table, $r$ value with double flag is significant at $\mathrm{p}<0.01$ level; $r$ values with single flag are significant at $p<0.05$ level. Actually $r \geq 0.393$ is significant at $p<0.01$ and $r \geq 0.304$ is significant at $p<0.05$.

- Whether the difference between means of the effect of the turnover factors on older employee and newer employee is significant or not, in the banking sector. To test the hypothesis we have used the ttest, this test tells us whether any significant difference between the means, occur or not.

\section{Formulae used:}

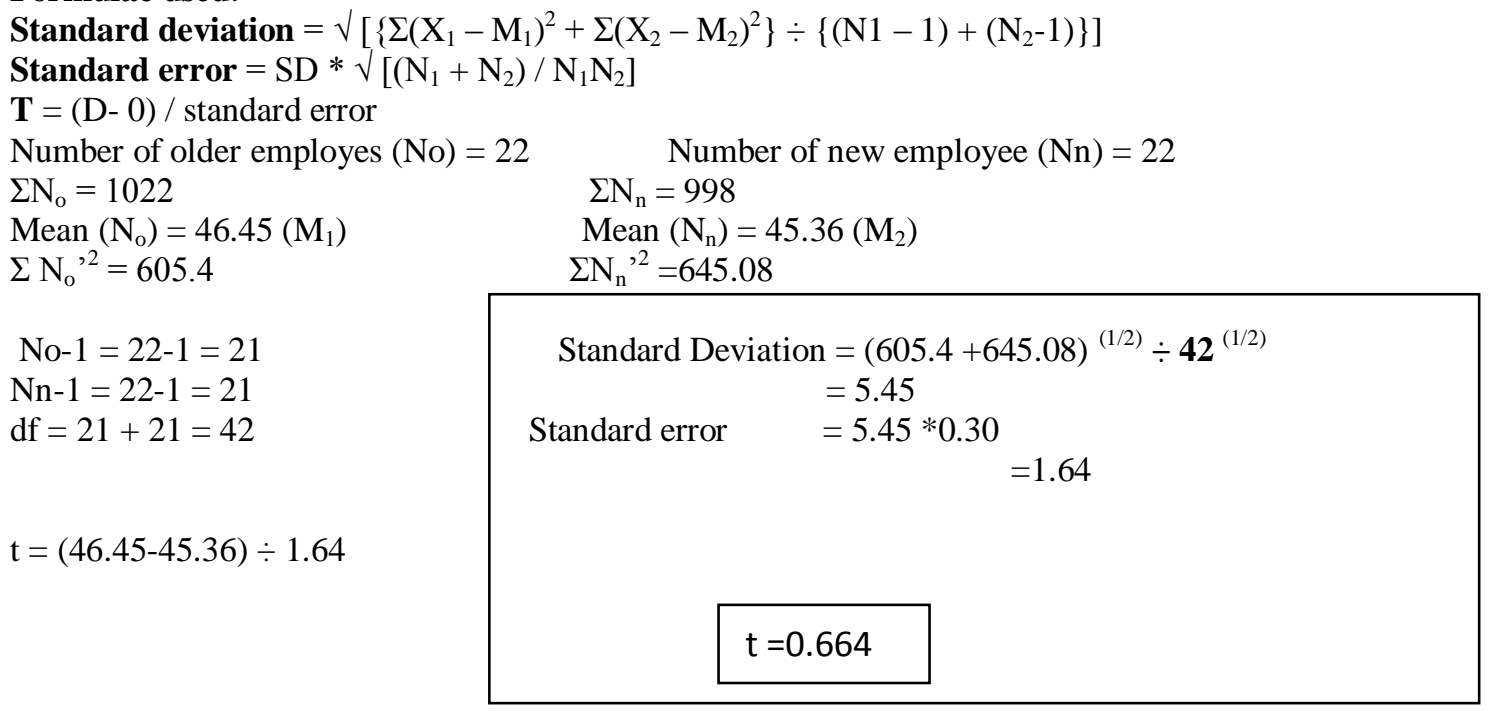

For $\mathrm{df}$ equal to $42, \mathrm{t}$ does not reach the 0.05 level, the obtained mean difference must be marked as "not significant". Hence our assumption was correct

\section{Findings:}

As evident from the results the prime factors for employee turnover in our respondent banks are job satisfaction and work environment. The high significance level for both variables show that, whether there is a salary compensation or not, employees have a gigantic desire to opt for new ventures in need of better work environment and job satisfaction. Comparative to above two variables the career development is having lesser but a quiet considerable significance. The people who counted career growth as their prime force for turnover have put a saddle on availability of opportunities and management relations as sub-prime forces. But they turn over for new venture for better wages or salary compensation.

So the good management can hold the employees for a longer period, by giving them satisfaction with respect to supervision and giving them much autonomy so that may not seek for alternates too often. In current situational study the possible solution for retaining career oriented employees would be to give them autonomy and ease from the management side. Extremely harsh attitude of the management and excessive workload will open the doors of alternate opportunities for career oriented employees. Employees do always seek for alternates because everyone wants to get flourished.

We also came with an outcome that no real mean difference exists as between the new employees and old employee's responses towards turnover factor.

\section{Limitations}

The generalization of the results is limited because instead of using psychological test, the study has evaluated on the self rating of the banking sector employees. The sample size is not large enough and do not cover all banks. The non-serious attitude of the respondent and other delicate issues might manipulate the responses to some extent. However, given the above mentioned limitations, the results of this study highlighted some significant factors and brought to light the need for the future research.

\section{Conclusion:}

No organization can succeed without its man at work which is Human Assets or Human Resources. Success of an organization depends upon its Human Resources. Due to dynamics nature of Human Resources, retaining talent becomes more challenging. More particularly, retention of the talent became most critical area of concern in the globalised world because of every organization competing others attracting talents with more 
attractive perks and opportunities. Talents are the future leaders. For betterment of the organization proper conglomeration of organizational requirements and the expectations of the human resources are to be strategically planned and implemented. Talents (HR) can save the organization in any short of problems. They can drive forward in any condition of the workplace and in any condition of the organization, if they are properly motivated, working with good environment and cooperation with co-workers. The relation with the workers and Manager should be positive, close and good. It is imperative for the firms to provide congenial and friendly environment for retaining and developing talents. Development of talent is the ultimate development of Organization.

\section{Reference:}

[1]. Ongori, H. (2007); A Review of the Literature on Employee Turnover, African Journal of Business Management pp. 049-054, June 2007

[2]. Banerjee ,S. and Guha ,S. (2008); Employee Attrition in EngineeringFirms: Case Study of DCIPS Pvt. Ltd, India, International Conference on Industrial Engineering and Operations Management, January 2010

[3]. Mobley, W. H., Griffeth, R. W., Hand, H. H., \& Meglino,B. M. Review and conceptual analysis of the employee turnover process. Psychological Bulletin, 1979, 86, 493-522.

[4]. March, J. G., \& Simon, H. A. Organizations. New York: John Wiley, 1958.

[5]. Michie, S and Williams, S (2003) 'Reducing psychological ill health and associated sickness absence: A systematic literature review', Occupational and Environmental Medicine, Volume 60, Pages 3-9

[6]. Mimura, $\mathrm{C}$ and Griffiths, 2003 'The effectiveness ofcurrent approaches to workplace stress management in the nursing profession: an evidence based literature review', Occupational and Environmental Medicine, Volume 60,Pages 10-15

[7]. Bashir, Asad 2007, Employees' Stress and Its Impacton Their Performance, First Proceedings of International Conference on Businessand Technology, Pages 156-161, Iqra University Islamabad.

[8]. Imtiaz,S and Ahmad,S (2010), Impact Of Stress On Employee Productivity, Performance And Turnover; An Important Managerial Issue.

[9]. Firth L, David J Mellor, Kathleen A Moore, Claude Loquet (2007). How can managers reduce employee intention to quit?, J. Manage. Psychol. 19 (2): 170-187.

[10]. Price, J.L (1977). The study of turnover, 1st edition, Iowa state university press, IA pp10-25

[11]. Kevin MM, Joan LC, Adrian JW (2004). “Organizational change and employee turnover” Personnel Rev. 33 (2):161-166.

[12]. Kuri, S and Dr. Alice,(2011). "Assessment of Causes of Labour Turnover in Three and Five Star -Rated Hotels in Kenya" International Journal of Business and Social Science Vol. 3 No. 15; August 2012.

[13]. Mbah,S.E. and Ikemefuna, C.O. (2011). "Job Satisfaction and Employees' Turnover Intentions in total Nigeria plc. in Lagos "International Journal of Humanities and Social Science Vol. 2 No. 14 [Special Issue - July 2012]

[14]. Agnes, M. (1999).Webster"s New World College Dictionary (4 ${ }^{\text {th }}$ Edition).New York, NY: Macmillian USA.

[15]. Shamsuzzoha, and Shumon,(2010)," Employee Turnover-a Study of its Causes and Effects to Different Industries in Bangladesh " International Journal of Humanities and Social Science [Special Issue - July 2012]

[16]. Khattak et al (2010) "Occupational stress and burnout in Pakistan's banking Sector" African Journal of Business Management Vol. 5(3), pp. 810-817, 4 February, 2011

[17]. Dr. Dwomoh and Korankye,T. (2012)" Labour turnover and its impact on performance of Banks in Ghana ". European Journal of Business and Management ISSN 2222-1905 (Paper) ISSN 2222-2839 (Online) Vol 4, No.7, 2012

[18]. Jaffari, A.R. et al (2011)." Prime and sub-prime factors of employee' voluntary turnover in boom phase of industry: Empirical evidence from banking sector of Pakistan" African Journal of Business Management Vol. 5(15), pp. 6408-6414, 4 August, 2011

[19]. Chruden, HJ \& Sherman, AW 1972, Personal management, South-Western, Philippine.

[20]. Clarke, et al (2010)."Retention, turnover and return - a longitudinal study of allied health professionals in Britain "Human Resource Management Journal, Vol 20, no 4, 2010, pages 391-406

[21]. ALI SHAH et al(2010)." Measuring Push, Pull And Personal Factors Affecting Turnover Intention: A Case Of University Teachers In Pakistan "Review Of Economic Business Studies. Volume 3, Issue 1, pp. 167-192, June 2010 ISSN-1843-763X

[22]. Samuel M.O. and Chipunza,C. (2009).” Employee retention and turnover: Using motivational variables as a panacea" African Journal of Business Management Vol.3 (8), pp. 410-415, September, 2009 